\title{
Karakteristik Pasien Lansia Sebelum Kemoterapi Pertama di RSUP Dr. M. Djamil Padang
}

\author{
Yunia Habsari ${ }^{1}$, Roza Mulyana ${ }^{2}$, Elmatris ${ }^{3}$ \\ ${ }_{1}$ Profesi Dokter Fakultas Kedokteran Universitas Andalas, Padang \\ 2Bagian IImu Penyakit Dalam Fakultas Kedokteran Universitas Andalas, Padang \\ 3Bagian Kimia Fakultas Kedokteran Universitas Andalas, Padang
}

\begin{abstract}
Latar Belakang. Penurunan fungsi tubuh dan gangguan organ akan memengaruhi karakteristik pasien lansia dengan kanker. Beberapa karakteristik pasien memengaruhi pemberian kemoterapi pada pasien lansia.

Objektif. Penelitian ini bertujuan untuk mengetahui karakteristik pasien lanjut usia yang akan menjalani kemoterapi pertama di RSUP M Djamil, Padang.
\end{abstract}

Metode. Penelitian ini merupakan penelitian deskriptif observasional dengan desain cross sectional. Data penelitian didapatkan dari rekam medik. Sampel penelitian sebanyak 110 pasien lansia yang akan menjalani kemoterapi pertama di RSUP dr. M. Djamil Padang periode Januari 2017 - Juli 2018.

Hasil. Sebagian besar pasien berada di kelompok usia 60 - 69 tahun (78,2\%). Karakteristik yang menonjol pada pasien yaitu haemoglobin dan hematokrit dibawah batas normal $\mathbf{7 3 , 6 \%}$ dan 70\% secara berurutan), sedangkan karakteristik lain cenderung normal. Jenis kanker paling sering pada pasien lansia adalah karsinoma mammae $(12,7 \%)$ dan karsinoma glotis $(11,8 \%)$ dengan obat kemoterapi yang sering digunakan yaitu paklitaksel $(13,1 \%)$, diikuti oleh sisplatin $(12,7 \%)$, siklofosfamid (11\%), karboplatin (10,6\%), dan vinkristin (10,2\%).

Kesimpulan. Sebagian besar pasien berada di kelompok usia lansia muda dan memiliki anemia, sedangkan karakteristik lainnya cenderung normal. Jenis kanker terbanyak adalah karsinoma mammae dan karsinoma glottis dengan obat kemoterapi yang paling banyak digunakan adalah paklitaksel dan sisplatin.

Kata kunci: Kanker, Kemoterapi, Lansia

Background. Decreased body function and organ dysfunction will affect the characteristic of elderly patients with cancer. Some characteristics will affect the chemotherapy given in elderly patients.

Objective. This study discussed the characteristics of elderly patients who received the first chemotherapy in RSUP dr. M. Djamil Padang. This research is an observational descriptive study with a cross sectional design.

Methods. The research data was obtained from the patient's medical record. The research sample consisted of one hundred and ten elderly patients who received first chemotherapy at
RSUP dr. M. Djamil Padang period January 2017 - July 2018.

Result. Most of the patients were in the age group $60-69$ years (78.2\%). Characteristics that stand out in elderly patients are the hemoglobin and hematocrit levels below normal limits $(73.6 \%$ and $70 \%$ respectively), while other characteristics tend to be normal. The most frequent types of cancer were breast carcinoma (12.7\%) and glottic carcinoma (11.8\%) and chemotherapy drugs that often used in patients are paclitaxel (13.1\%), followed by cisplatin (12.7\%), cyclophosphamide (11\%), carboplatin (10.6\%), and vincristine (10.2\%).

Conclusion. Most of patients were in the young elderly age group and had anaemia, while other characteristics tend to be normal. The most frequent types of cancer are breast carcinoma and glottic carcinoma with the most widely used chemotherapy drugs are paclitaxel and cisplatin.

Keywords: Cancer, Chemotherapy, Elderly

\section{Apa yang sudah diketahui tentang topik ini?}

Karakteristik pasien lansia dilaporkan lebih bervariasi. Kakteristik pasien dapat menyebabkan perubahan farmakokinetik dan farmakodinamik obat kemoterapi.

Apa yang ditambahkan pada studi ini?

Sebagian besar pasien lansia berada di kelompok usia lansia muda dan memiliki nilai hemoglobin dan kadar hematokrit dibawah batas normal, sedangkan karakteristik lainnya cenderung normal.

\section{CORRESPONDING AUTHOR}

Phone: +6285374164202

E-mail:yhabsari@gmail.com

ARTICLE INFORMATION

Received: July $29^{\text {th }}, 2020$

Revised: April $8^{\text {th }}, 2021$

Available online: May $27^{\text {th }}, 2021$ 


\section{Pendahuluan}

Salah satu penyakit yang menakutkan bagi sebagian besar masyarakat pada saat ini ialah kanker. Kanker adalah pertumbuhan dan penyebaran sel yang tidak terkontrol yang dapat memengaruhi hampir semua bagian tubuh.1 Di Indonesia, terdapat 299.700 kasus kanker baru per tahun dan 194.500 kematian akibat kanker per tahunnya. Sekitar $70 \%$ kematian akibat kanker terjadi di negara berpenghasilan rendah dan menengah. Data tersebut menunjukan tingginya angka kematian akibat kanker di negara berkembang (termasuk Indonesia). Namun, hanya 1 dari 5 negara berpenghasilan rendah dan menengah yang memiliki data yang diperlukan untuk mendorong kebijakan kanker tersebut.2

Salah satu populasi yang rentan menderita kanker adalah lansia (lanjut usia). Menurut UU RI No. 13 tahun 1998, lanjut usia (lansia) adalah seseorang yang telah mencapai usia 60 (enam puluh) tahun ke atas.3 Di Indonesia, pada tahun 2013 prevalensi penyakit kanker tertinggi berada pada kelompok umur 75 tahun ke atas, yaitu sebesar 5,0 \%o, kemudian disusul oleh tingkat umur 65-74 tahun sebesar 3,9 \%o.4 Peningkatan jumlah kanker, diduga berhubungan dengan perubahan yang terjadi akibat proses penuaan, durasi paparan karsinogen dan pertumbuhan massa tumor yang berlangsung lama pada lanjut usia. 5

Populasi lansia di Indonesia diprediksi terus akan mengalami peningkatan. Menurut data proyeksi penduduk, diperkirakan tahun 2017 terdapat 23,66 juta jiwa penduduk lansia di Indonesia (9,03\%), tahun 2020 (27,08 juta), tahun 2025 (33,69 juta), tahun 2030 (40,95 juta) dan tahun 2035 (48,19 juta). 6

Kanker pada lansia sering ditemukan pada stadium yang lebih lanjut atau sudah metastasis sehingga tidak bisa di operasi. Kemoterapi bisa menjadi pilihan tatalaksana dalam memperbaiki kualitas hidup dan kelangsungan hidup lansia.7 Kemoterapi adalah pemberian satu atau lebih obat sitotoksik untuk menghancurkan atau menghambat pertumbuhan dan pembelahan selsel ganas dalam pengobatan kanker.8

Rencana pemberian kemoterapi pada lansia tergantung kondisi pasien. Beberapa karakteristik pasien seperti usia, jenis kelamin, status gizi cadangan sumsum tulang, fungsi ginjal dan hati, gangguan organ dapat memengaruhi pemberian kemoterapi. Hal tersebut dapat menyebabkan perubahan farmakokinetik dan farmakodinamik dari obat kemoterapi dan memengaruhi pengobatan pada pasien lansia.7,9

Penelitian yang dilakukan di RSUP Dr M Djamil Padang pada pasien lansia dengan leukimia myeloblastik akut periode Januari 2015 Desember 2017, mendapatkan karakteristik pasien lansia sebelum kemoterapi menunjukkan pasien mengalami anemia (58.3\%), leukositosis (58.3\%), trombositopenia berat (58.3\%).10

Penelitian mengenai karakteristik pasien lansia juga telah dilakukan di RSUD dr Soetomo Surakarta pada pasien kanker paru periode Januari-Desember 2006, didapatkan distribusi pasien terbanyak pada kelompok usia 61-70 tahun sebanyak $37 \%$ dengan kemoterapi terbanyak yang digunakan adalah karboplatinpaklitaksel (65\%).11

Kurangnya data karakteristik pasien lansia yang menjalani kemoterapi dari beberapa penelitian yang dilakukan, maka perlu diketahui karakteristik pasien lansia yang menjalani kemoterapi, khususnya di RSUP Dr. M. Djamil Padang. Penelitian ini diharapkan bisa menambah data mengenai karakteristik pasien lansia yang menjalani kemoterapi dan obat kemoterapi yang diberikan. Data tersebut dapat menggambarkan situasi pemberian kemoterapi pada lansia dan diharapkan dapat menjadi referensi bagi peneliti lain untuk penelitian analisis penggunaan kemoterapi lebih lanjut, khususnya di RSUP Dr. M. Djamil Padang.

\section{Metode}

Penelitian ini merupaka penelitian deskriptif, yaitu dengan mengumpulkan data dari rekam medis pasien usia lanjut. Jenis penelitian adalah studi observasional dengan desain cross sectional. Penelitian ini dilaksanakan di bagian rekam medik dan unit kemoterapi RSUP Dr. M. Djamil Padang. Penelitian dilaksanakan mulai Juni 2018 - Januari 2019.

Populasi penelitian adalah pasien lanjut usia yang menjalani kemoterapi di unit kemoterapi RSUP Dr. M. Djamil Padang periode Januari 2017Juli 2018. Sampel penelitian merupakan populasi yang memenuhi kriteria inklusi dan eksklusi. Kriteria inklusi subjek: Pasien lanjut usia $(\geqslant 60$

Yunia Habsari 
tahun) yang menjalani kemoterapi di unit kemoterapi RSUP Dr. M. Djamil Padang periode Januari 2017- Juli 2018. Kriteria eksklusi subjek: Pasien dengan data pemeriksaan sebelum kemoterapi pertama yang dibutuhkan untuk penelitian tidak lengkap. Teknik sampling yang digunakan dalam penelitian ini adalah total sampling

Data dikumpulkan dari rekam medis RSUP Dr. M. Djamil Padang periode Januari 2017- Juli 2018. Data yang diambil adalah sebagai berikut : nomor rekam medis, usia pasien, jenis kelamin, berat badan, tinggi badan, indeks masa tubuh, hasil laboratorium pasien (haemoglobin, haematokrit, leukosit, trombosit, SGOT, SGPT, kreatinin, perhitungan eGFR, albumin, gula darah sewaktu), jenis kanker yang menyebabkan pasien lansia menjalani kemoterapi dan obat kemoterapi yang diberikan pada pasien.

Data yang telah dikumpulkan oleh peneliti kemudian akan diolah menggunakan program computer. Analisis data yang dilakukan adalah analisis data univariat pada setiap variabel dengan menggunakan program komputer. Pada analisis univariat, data yang berskala nominal dinyatakan dalam distribusi frekuensi.

\section{Hasil}

Penelitian ini telah dilaksanakan menggunakan data rekam medis secara retrospektif. Subjek penelitian yang dijadikan sampel penelitian dan memenuhi kriteria inklusi dan eksklusi adalah 110 pasien. Berdasarkan data rekam medis yang ada didapatkan hasil sebagai berikut.

Pada penelitian ini didapatkan frekuensi jenis kanker tertinggi pada pasien lansia adalah karsinoma mammae (12,7\%), disusul oleh karsinoma glotis $(11,8 \%)$, limfoma non- hodgkin, karsinoma servix, dan leukimia dengan masing masingnya sebanyak 9,1\%.

Karakteristik pasien lanjut usia yang akan menjalani kemoterapi pertama di RSUP Dr. M. Djamil Padang dapat dilihat pada tabel 1.

Berdasarkan tabel 1 dapat dilihat bahwa frekuensi terbesar pasien lansia yang akan menjalani kemoterapi pertama terdapat pada kelompok usia 60-69 tahun sebesar 78,2 \% disusul kelompok usia 70-79 tahun sebesar 19,1\%. Berdasarkan jenis kelamin, distribusi jumlah pasien laki-laki sama banyak dengan pasien perempuan yaitu masing masing $50 \%$.
Pasien paling banyak memiliki kadar haemoglobin rendah yaitu pada pasien laki - laki sebesar $44,5 \%$ dan pada pasien perempuan sebesar $29,1 \%$ dari total pasien. Nilai haematokrit juga terbanyak pada kelompok hematokrit rendah yaitu pada pasien laki-laki sebesar 39,1\% dan pada pasien perempuan sebesar $30,9 \%$ dari total pasien. Jumlah leukosit dan trombosit dengan frekuensi terbanyak terdapat pada kelompok normal sebesar $61,8 \%$ dan $59,1 \%$ masingmasingnya.

Pasien paling banyak memiliki SGOT pada kelompok normal yaitu pada pasien laki - laki sebesar $49,1 \%$ dan pada pasien perempuan sebesar $41,8 \%$ dari total pasien. SGPT juga terbanyak pada kelompok SGPT normal yaitu pada pasien laki-laki sebesar $48,2 \%$ dan pada pasien perempuan sebesar $44,5 \%$ dari total pasien.

Distribusi frekuensi kadar kreatinin serum pasien dengan frekuensi paling banyak terdapat pada kelompok normal sebesar $80 \%$. Frekuensi eGFR paling banyak terdapat pada kelompok nilai $\geq 60 \mathrm{~mL} / \mathrm{min} / 1.73 \mathrm{~m}^{2}$ yaitu sebesar $81,8 \%$. Kadar albumin dengan distribusi frekuensi paling banyak terdapat pada kelompok normal yaitu sebesar $60,9 \%$ disusul kelompok rendah sebesar 38,2\%. Distribusi frekuensi kadar gula darah sewaktu pasien terbanyak pada kelompok normal sebesar 93,6\%.

Sedangkan karakteristik pasien lanjut usia yang akan menjalani kemoterapi pertama berdasarkan berat badan, tinggi badan, dan indeks masa tubuh di RSUP Dr. M. Djamil Padang dapat dilihat pada tabel 2 . 
Tabel 1. Karakteristik Pasien Lanjut Usia yang Akan Menjalani Kemoterapi Pertama di RSUP dr. M. Djamil Padang.

\begin{tabular}{|c|c|c|c|}
\hline \multirow[t]{2}{*}{ Variabel } & \multicolumn{3}{|c|}{$\begin{array}{c}\text { Frekuensi (\%) } \\
n=110\end{array}$} \\
\hline & Laki-laki & Perempuan & Total \\
\hline \multicolumn{4}{|l|}{ Usia } \\
\hline $60-69$ tahun & $39(35,5)$ & $47(42,7)$ & $86(78,2)$ \\
\hline $70-79$ tahun & $15(13,6)$ & $6(5,5)$ & $21(19,1)$ \\
\hline$\geq 80$ tahun & $2(1,8)$ & $1(0,9)$ & $3(2,7)$ \\
\hline Jenis Kelamin & $55(50)$ & $55(50)$ & $110(100)$ \\
\hline \multicolumn{4}{|l|}{ Kadar haemoglobin } \\
\hline L: $<14$ g/dl; P:<12 g/dl (Rendah) & $49(44,5)$ & $32(29,1)$ & $81(73,6)$ \\
\hline L: $14-18 \mathrm{~g} / \mathrm{dl} ; \mathrm{P}: 12-16 \mathrm{~g} / \mathrm{dl}$ (Normal) & $6(5,5)$ & $23(20,9)$ & $29(26,4)$ \\
\hline L: >18g/dl; P: >16 g/dl (Tinggi) & $0(0)$ & $0(0)$ & $0(0)$ \\
\hline \multicolumn{4}{|l|}{ Nilai haematokrit } \\
\hline L: $<40 \%$; P: $<37 \%$ (Rendah) & $43(39,1)$ & $34(30,9)$ & $77(70)$ \\
\hline L: 40-48\%; P: 37-43\% (Normal) & $11(10,0)$ & $21(19,1)$ & $32(29)$ \\
\hline L: >48\%; P: >43\% (Tinggi) & $1(0,9)$ & $0(0)$ & $1(0,9)$ \\
\hline \multicolumn{4}{|l|}{ Leukosit } \\
\hline$<5000 / \mathrm{mm}^{3}$ (Rendah) & $7(6,4)$ & $8(7,3)$ & $15(13,6)$ \\
\hline $5000-10.000 / \mathrm{mm}^{3}$ (Normal) & $35(31,8)$ & $33(30)$ & $68(61,8)$ \\
\hline$>10.000 / \mathrm{mm}^{3}$ (Tinggi) & $14(12,3)$ & $13(11,8)$ & $27(24,5)$ \\
\hline \multicolumn{4}{|l|}{ Trombosit } \\
\hline$<150.000 / \mathrm{mm}^{3}$ (Rendah) & $12(10,9)$ & $8(7,3)$ & $20(18,2)$ \\
\hline $150.000-400.000 / \mathrm{mm}^{3}$ (Normal) & $28(25,5)$ & $37(33,6)$ & $65(59,1)$ \\
\hline$>400.000 / \mathrm{mm}^{3}$ (Tinggi) & $16(14,5)$ & $9(8,2)$ & $25(22,7)$ \\
\hline \multicolumn{4}{|l|}{ SGOT } \\
\hline L: $<38$ u/l; P: $<32$ u/l (Normal) & $54(49,1)$ & $46(41,8)$ & $100(90,9)$ \\
\hline L: $\geq 38$ u/l; P: $\geq 32$ u/l (Meningkat) & $1(0,9)$ & $9(8,2)$ & $10(9,1)$ \\
\hline \multicolumn{4}{|l|}{ SGPT } \\
\hline L: $<41$ u/l; P: $<31$ u/l (Normal) & $53(48,2)$ & $49(44,5)$ & $102(92,7)$ \\
\hline $\mathrm{L}: \geq 41 \mathrm{u} / \mathrm{l} ; \mathrm{P}: \geq 31 \mathrm{u} / \mathrm{l}$ (Meningkat) & $2(1,8)$ & $6(5,5)$ & $8(7,3)$ \\
\hline \multicolumn{4}{|l|}{ Kreatinin } \\
\hline $0,6-1,1 \mathrm{mg} / \mathrm{dl}$ (Normal) & $42(38,1)$ & $47(42,7)$ & $88(80)$ \\
\hline$>1,1 \mathrm{mg} / \mathrm{dl}$ (Meningkat) & $14(12,7)$ & $7(6,4)$ & $22(20)$ \\
\hline \multicolumn{4}{|l|}{ eGFR } \\
\hline$<60 \mathrm{~mL} / \mathrm{min} / 1.73 \mathrm{~m}^{2}$ & $11(10)$ & $9(8,2)$ & $20(18,2)$ \\
\hline$\geq 60 \mathrm{~mL} / \mathrm{min} / 1.73 \mathrm{~m}^{2}$ & $45(40,9)$ & $45(40,9)$ & $90(81,8)$ \\
\hline \multicolumn{4}{|l|}{ Albumin } \\
\hline$<3.8 \mathrm{~g} / \mathrm{dl}$ (Rendah) & $18(16,4)$ & $24(21,8)$ & $42(38,2)$ \\
\hline $3.8-5 \mathrm{~g} / \mathrm{dl}$ (Normal) & $38(34,5)$ & $29(26,4)$ & $67(60,9)$ \\
\hline$>5$ g/dl (Tinggi) & $1(0,9)$ & $0(0)$ & $1(0,9)$ \\
\hline \multicolumn{4}{|l|}{ Gula Darah Sewaktu } \\
\hline$<200 \mathrm{mg} / \mathrm{dl}$ (Normal) & $50(45,5)$ & $53(48,2)$ & $103(93,6)$ \\
\hline$\geq 200$ mg/dl (Tinggil) & $6(5,5)$ & $1(0,9)$ & $7(6,4)$ \\
\hline \multicolumn{4}{|l|}{ Jenis Kanker } \\
\hline Karsinoma Mammae & 0 & $100(90,9)$ & $14(12,7)$ \\
\hline Karsinoma Glotis & $12(10,9)$ & $1(0,9)$ & $13(11,8)$ \\
\hline Limfoma non-Hodgkin & $8(7,3)$ & $2(1,8)$ & $10(9,1)$ \\
\hline Karsinoma Servix & $0(0)$ & $10(9,1)$ & $10(9,1)$ \\
\hline Leukemia & $5(4,5)$ & $5(4,5)$ & $10(9,1)$ \\
\hline Karsinoma Bronkogenik & $8(7,3)$ & $1(0,9)$ & $9(8,2)$ \\
\hline Karsinoma Nasofaring & $6(5,5)$ & $1(0,9)$ & $7(6,4)$ \\
\hline Karsinoma Ovarium & $7(6,4)$ & $0(0)$ & $7(6,4)$ \\
\hline Karsinoma Rekti & $3(2,7)$ & $3(2,7)$ & $6(5,5)$ \\
\hline Karsinoma Buli & $2(1,8)$ & $3(2,7)$ & $5(4,5)$ \\
\hline Karsinoma Sinonasal & $1(0,9)$ & $2(1,8)$ & $3(2,7)$ \\
\hline SCC Oral Cavity & $1(0,9)$ & $1(0,9)$ & $2(1,8)$ \\
\hline Karsinoma Paru & $2(1,8)$ & $0(0)$ & $2(1,8)$ \\
\hline
\end{tabular}




\begin{tabular}{|c|c|c|c|}
\hline \multirow[t]{2}{*}{ Variabel } & \multicolumn{3}{|c|}{$\begin{array}{c}\text { Frekuensi (\%) } \\
n=110\end{array}$} \\
\hline & Laki-laki & Perempuan & Total \\
\hline Karsinoma Endometrium & $0(0)$ & $2(1,8)$ & $2(1,8)$ \\
\hline dll yang tidak masuk kategori diatas* & $8(7,3)$ & $2(1,8)$ & $10(9,1)$ \\
\hline
\end{tabular}

Ket $: *$ Karsinoma Parotis, SCC leher, Karsinoma Colon, Limfoma Hodgkin, Karsinoma Prostat, Angiosarcoma, Liposarcoma, Multiple Mieloma, Hepatoselular cholangio carsinoma, Springoadenocarsinoma Papiloforum

Tabel 2. Karakteristik Pasien Lanjut Usia yang Akan Menjalani Kemoterapi Pertama Berdasarkan Berat Badan, Tinggi Badan, dan Indeks Masa Tubuh

\begin{tabular}{lccc}
\hline \multicolumn{1}{c}{ Variabel } & $\begin{array}{c}\text { Median } \\
\text { (Min, } \\
\text { Max) }\end{array}$ & $\begin{array}{c}\text { Rerata } \\
\text { (SD) }\end{array}$ & $\begin{array}{c}\text { Frekuensi } \\
\text { (\%) } \\
\mathbf{n = 1 1 0}\end{array}$ \\
\hline Berat Badan & $\begin{array}{c}52,00 \\
(34,95)\end{array}$ & & \\
\hline Tinggi Badan & & 157,5 & \\
& & $(7,4)$ & \\
\hline IMT & & $21(19,1)$ \\
$\quad \begin{array}{l}\text { Kategori kurus } \\
<18.5\end{array}$ & & $75(68,2)$ \\
$\begin{array}{l}\text { Kategori Normal } \\
\geq 18.5-<24.9\end{array}$ & & $6(5,5)$ \\
$\begin{array}{l}\text { KategoriBB lebih } \\
\geq 25.0-<27.0\end{array}$ & & $8(7,3)$ \\
$\begin{array}{l}\text { Kategori Obesitas } \\
>27.0\end{array}$ & & \\
\hline
\end{tabular}

Frekuensi tertinggi nilai IMT pasien terdapat pada kelompok normal yaitu sebesar $68,2 \%$ dan disusul oleh kategori kurus sebesar 19,1\%.

Distribusi frekuensi obat kemoterapi yang akan digunakan pasien lanjut usia yang akan menjalani kemoterapi pertama dapat dilihat pada tabel 3.

Tabel 3. Distribusi Frekuensi Obat Kemoterapi yang digunakan Pasien Lanjut Usia yang Akan Menjalani Kemoterapi Pertama di RSUP dr. M. Djamil Padang.

\begin{tabular}{lc}
\hline \multicolumn{1}{c}{ Obat Kemoterapi } & $\begin{array}{c}\text { Frekuensi (\%) } \\
\mathbf{n = 2 4 5}\end{array}$ \\
\hline Paklitaksel & $32(13,1)$ \\
Sisplatin & $31(12,7)$ \\
Siklofosfamid & $27(11)$ \\
Karboplatin & $26(10,6)$ \\
Vinkristin & $25(10,2)$ \\
Doksorubisin & $23(9,4)$ \\
5 FU & $14(5,7)$ \\
Oksaliplatin & $12(4,9)$ \\
Bleomisin & $11(4,5)$ \\
Dosetaksel & $11(4,5)$ \\
Gemsitabin & $9(3,7)$ \\
Daunorubisin & $7(2,9)$ \\
Sitarabin & $3(1,2)$ \\
Dakarbazin & $2(0,8)$ \\
Epirubisin & $2(0,8)$ \\
\hline
\end{tabular}

\begin{tabular}{lc}
\hline \multicolumn{1}{c}{ Obat Kemoterapi } & $\begin{array}{c}\text { Frekuensi (\%) } \\
\boldsymbol{n = 2 4 5}\end{array}$ \\
\hline Fludarabin & $2(0,8)$ \\
Ifosfamid & $2(0,8)$ \\
Vinorelbin & $2(0,8)$ \\
dll yang tidak termasuk diatas* & $4(1,6)$ \\
\hline Ket : ${ }^{*}$ = Etoposid, Kapesitabin, Vinblastin, Rituksimab
\end{tabular}

Tabel 3 memperlihatkan bahwa obat kemoterapi yang sering digunakan pada pasien yaitu paklitaksel $(13,1 \%)$, diikuti oleh sisplatin $(12,7 \%)$, siklofosfamid (11\%), karboplatin $(10,6 \%)$, dan vinkristin $(10,2 \%)$.

\section{Pembahasan}

Pada penelitian didapatkan data frekuensi jenis kanker tertinggi adalah karsinoma mammae sebanyak 14 orang (12,7\%), disusul oleh karsinoma glotis sebanyak 13 orang $(11,8 \%)$. Beberapa faktor risiko karsinoma mammae adalah genetik, faktor hormonal, peningkatan eksposur terhadap hormon estrogen, pola diet makanan berlemak frekuensi tinggi dan lingkungan. Studi Harahap, et al menyatakan bahwa $65 \%$ pasien karsinoma mammae premenopause di kota Padang mengalami metilasi promoter pada gen BRCA1. ${ }^{12}$ Hubungan antara diet makanan berlemak dengan risiko karsinoma mammae masih belum diketahui secara pasti. Studi Studi oleh Neila Sulung pada penderita karsinoma mammae di RS Dr. Achmad Mochtar kota Buktittinggi mendapatkan $62 \%$ dari kejadian karsinoma mammae memiliki riwayat mengonsumsi makanan tinggi lemak. ${ }^{13}$

Pada penelitian ini data frekuensi jenis kanker tertinggi setelah karsinoma mammae adalah karsinoma glotis. Karsinoma glotis merupakan salah satu bagian dari subsite dari karsinoma laring. Berdasarkan data Surveillance, Epidemiology, and End Results menunjukan karsinoma laring termasuk keganasan yang jarang dan menempati urutan ke- 21 dari seluruh jenis kanker di Amerika Serikat, namun 52,7\% dari pasien yang didiagnosis karsinoma laring pada tahun 2011-2015 berusia $\geq 65$ tahun. ${ }^{14}$ Studi oleh 
Cahyadi pada pasien karsinoma laring di departemen ilmu kesehatan telinga hidung tenggorok bedah kepala leher rumah sakit Hasan Sadikin Bandung Januari 2013-Juli 2015 didapatkan data $44 \%$ pasien berusia $\geq 60$ tahun dengan faktor risiko utama adalah merokok $(99 \%){ }^{15}$

Berdasarkan penelitian, diperoleh data bahwa pasien lansia yang menjalani kemoterapi terbanyak berada di kelompok usia lansia muda (60-69 tahun) yaitu sebesar 78,2\%. Hasil ini sejalan dengan penelitian Hurria, et al pada pasien lansia yang akan kemoterapi di Amerika Serikat, mendapatkan frekuensi terbesar pasien lansia yang menjalani kemoterapi pada kelompok usia 60-69 tahun. ${ }^{16}$ Pada CARG (Cancer and Aging Research Group) scoring tool, usia $\geq 72$ tahun merupakan salah satu faktor risiko untuk toksisitas kemoterapi. ${ }^{17}$

Berdasarkan penelitian, diperoleh frekuensi tertinggi nilai IMT pasien terdapat pada kelompok normal yaitu sebesar $68,2 \%$ dan disusul oleh kategori kurus $(19,1 \%)$, obesitas $(7,3 \%)$ dan berat badan lebih $(5,5 \%)$. Status gizi yang baik menjadi salah satu pertimbangan dalam pemberian kemoterapi. Penurunan berat badan pada pasien kanker bisa terjadi akibat gangguan metabolik karena kanker, peningkatan sitokin proinflamatori dan laktat (memodulasi neurotransmitter sistem saraf pusat yang memengaruhi nafsu makan) dan faktor psikososial. ${ }^{18}$

Berdasarkan penelitian, diperoleh data pasien paling banyak memiliki kadar haemoglobin rendah yaitu pada pasien laki - laki sebesar $44,5 \%$ dan pada pasien perempuan sebesar 29,1\% dari total pasien. Nilai haematokrit juga terbanyak pada kelompok hematokrit rendah yaitu pada pasien laki-laki sebesar 39,1\% dan pada pasien perempuan sebesar $30,9 \%$ dari total pasien.

Hal ini sejalan dengan penelitian Owusu, et al pada pasien lansia yang akan menjalani kemoterapi yaitu didapatkan data 51\% memiliki kadar haemoglobin rendah. ${ }^{19}$ Rendahnya kadar haemoglobin ini bisa terjadi karena kondisi terkait kanker (seperti inflitrasi sum-sum tulang, malnutrisi, dll) dan kondisi terkait pasien (yaitu penyakit yang terjadi bersamaan dengan kanker seperti thalassemia, hemoglobinopati, dll). ${ }^{20}$ Sitokin akibat kanker seperti tumor necrosis factor-alpha (TNF- $\alpha$ ), perubahan growth factor- beta, interleukin (IL)-1, IL-6, and interferongamma akan memodulasi metabolisme besi sehingga mengurangi efek eritropoietin dan memengaruhi produksi eritrosit normal. ${ }^{21}$

Pada penelitian ini, diperoleh data jumlah leukosit dengan frekuensi terbanyak terdapat pada kelompok jumlah leukosit normal (5000$10.000 / \mathrm{mm}^{3}$ ) sebesar $61,8 \%$, disusul kelompok jumlah leukosit tinggi $\left(>10.000 / \mathrm{mm}^{3}\right)$ sebesar $25,5 \%$ dan kelompok jumlah leukosit rendah $\left(<5000 / \mathrm{mm}^{3}\right)$ sebesar $13,6 \%$. Studi oleh Connolly, et al menyatakan leukositosis pada pasien kanker terjadi akibat proses inflamasi pada keganasan yang lebih agresif, akibat komorbid yang signifikan, inflamasi atau akibat progresivitas kanker yang terkait leukosit. Sedangkan leukosit yang rendah pada pasien kanker dapat terjadi akibat gangguan sumsum tulang (pada leukemia atau akibat invasi kanker ke sumsum tulang) dan tatalaksana kanker (sepert kemoterapi dan radioterapi). ${ }^{22}$

Pada penelitian ini, diperoleh data jumlah trombosit dengan frekuensi terbanyak terdapat pada kelompok normal $\left(400.000 / \mathrm{mm}^{3}\right)$ yaitu sebesar 59,1\%, disusul kelompok tinggi $>400.000$ $/ \mathrm{mm}^{3}$ ) sebesar $22,7 \%$ dan kelompok rendah $\left(<150.000 / \mathrm{mm}^{3}\right)$ sebesar $18,2 \%$. Studi oleh Liebman, et al trombosit yang rendah pada pasien kanker dapat terjadi akibat infiltrasi tumor pada sum-sum tulang, kemoterapi, dan gangguan mikroangiopati pada pasien. Pasien kanker dengan trombosit yang rendah memerlukan terapi transfusi trombosit untuk mencegah risiko perdarahan. ${ }^{23}$

Berdasarkan penelitian, diperoleh data pasien paling banyak memiliki SGOT pada kelompok normal yaitu pada pasien laki - laki sebesar $49,1 \%$ dan pada pasien perempuan sebesar $41,8 \%$ dari total pasien. SGPT juga terbanyak pada kelompok SGPT normal yaitu pada pasien laki-laki sebesar $48,2 \%$ dan pada pasien perempuan sebesar 44,5 $\%$ dari total pasien. SGOT dan SGPT yang meningkat pada pasien kanker dapat terjadi akibat penyakit hati yang sudah ada sebelumnya (perlemakan hati, sirosis hepatitis, dll), karsinoma hepatoselular dan metastasis hati. ${ }^{24}$ Penelitian oleh Jorgensen, et al pada pasien lansia yang akan kemoterapi didapatkan data 0,3\% pasien kanker memiliki disfungsi hati. ${ }^{25}$

Berdasarkan penelitian didapatkan data distribusi frekuensi kadar kreatinin serum pasien

Yunia Habsari 
terbanyak terdapat pada kelompok normal $(0,6-$ $1,1 \mathrm{mg} / \mathrm{dl}$ ) sebesar $80 \%$. Data frekuensi kelompok nilai kreatinin yang meningkat didapatkan sebesar 20. Distribusi frekuensi nilai eGFR terbanyak terdapat pada kelompok nilai $\geq 60$ $\mathrm{mL} / \mathrm{min} / 1.73 \mathrm{~m}^{2}$ yaitu sebesar $81,8 \%$. Sedangkan kelompok eGFR $<60 \mathrm{~mL} / \mathrm{min} / 1.73 \mathrm{~m}^{2}$ didapatkan sebesar 18,2. Kreatinin yang meningkat dan eGFR dengan nilai $<60 \mathrm{~mL} / \mathrm{min} / 1.73 \mathrm{~m}^{2}$ pada pasien menunjukkan terdapatnya penurunan fungsi ginjal. Penelitian oleh Jorgensen, et al pada pasien lansia didapatkan data $0,7 \%$ pasien memiliki gangguan fungsi ginjal. ${ }^{25}$

Kadar albumin dengan distribusi frekuensi terbanyak terdapat pada kelompok normal (3.8-5 $\mathrm{g} / \mathrm{dl}$ ) yaitu sebesar 60,9\%. Disusul oleh kelompok albumin rendah sebesar 38,2\% dan albumin tinggi sebesar $0,9 \%$. Albumin sering digunakan sebagai indikator status nutrisi. Studi oleh Shaiba, et al menyatakan albumin rendah pada pasien kanker terjadi kekurangan nutrisi akibat tumor atau yang berhubungan dengan ukuran dan lokasi tumor tersebut. $^{26}$

Distribusi frekuensi nilai gula darah sewaktu pasien juga terbanyak pada kelompok normal $(<$ $200 \mathrm{mg} / \mathrm{dl}$ ) sebesar 93,6\%. Menurut studi Hwangbo, et al menyatakan gula darah tinggi pada pasien kanker dapat terjadi dikarenakan faktor risiko yang mirip antara diabetes mellitus dengan kanker, yaitu usia tua, laki-laki, obesitas, kurangnya aktifitas fisik, diet tinggi kalori dan merokok. Stress akut selama kemoterapi juga bisa meningkatkan resistensi insulin yang dapat menyebabkan hiperglikemia. ${ }^{27}$

Dari hasil penelitian didapatkan bahwa karakteristik pasien lansia yang akan menjalani kemoterapi cenderung normal kecuali nilai haemoglobin dan haematokrit. Hal ini bisa dikarenakan, nilai yang adekuat pada pemeriksaan darah, fungsi ginjal dan fungsi hati diperlukan untuk memulai kemoterapi, bila hasil pemeriksaan terlalu rendah, hal ini akan memengaruhi dosis obat yang diberikan hingga bisa menyebabkan penundaan dalam pemberian kemoterapi. Hal ini disebabkan obat kemoterapi tertentu bersifat nefrotoksisitas, hepatotoksi dan myelosupresi. Penelitian oleh Hurria $\mathrm{A}$, et al menemukan toksisitas hematologi grade 3 sampai 5 terjadi masing-masing pada $26 \%$ dan $43 \%$ pada lansia dengan toksisitas paling umum adalah neutropenia (11\%), leukopenia (10\%), dan anemia (10\%). ${ }^{28}$

Berdasarkan penelitian didapatkan data obat kemoterapi yang sering digunakan pada pasien lansia yaitu Paklitaksel (13,1\%), disusul oleh Sisplatin (12,7\%), Siklofosfamid (11\%), Karboplatin (10,6\%), dan Vinkristin (10,2\%). Seringnya penggunaan obat-obatan tersebut mungkin dipengaruhi oleh jenis kanker yang sering terjadi. Paklitaksel digunakan untuk penatalaksanaan Karsinoma mammae, ovarium dan paru melalui melalui penahanan proses mitosis sehingga menginduksi kematian sel. Paklitaksel juga sering digunakan secara off label untuk keganasan gastroesofageal, endometrial, servikal, prostat, dan keganasan kepala dan leher. ${ }^{29}$ Sedangkan sisplatin digunakan untuk keganasan kepala dan leher, karsinoma mammae, buli, paru dan ovarium. ${ }^{30}$

\section{Simpulan}

Dari hasil penelitian, dapat disimpulkan jenis kanker paling banyak pada pasien lansia yang akan menjalani kemoterapi pertama di RSUP dr. M. Djamil Padang adalah karsinoma mammae dan karsinoma glotis. Sebagian besar pasien berada di kelompok usia 60 - 69 tahun dengan jenis kelamin laki-laki dan perempuan sama banyak. Obat kemoterapi yang paling banyak digunakan adalah paklitaksel dan sisplatin. Karakteristik yang menonjol pada pasien yaitu sebagian besar pasien memiliki anemia, sedangkan karakteristik lainnya cenderung normal.

\section{Ucapan Terima Kasih}

Terima kasih kepada semua pihak yang telah membantu dalam pelaksanaan penelitian. Kepada Direktur Umum RSUP Dr. M Djamil Padang yang telah memberikan izin melaksanakan penelitian dan kepada staf bagian rekam medik yang telah membantu penulis dalam melaksanakan penelitian.

\section{Daftar Pustaka}

1. Dharmojo B. Kanker pada usia lanjut. Dalam: Dharmojo B, editor (penyunting). Buku ajar boedhi darmojo geriatri ilmu kesehatan usia lanjut. Edisi ke4. Semarang: Balai Penerbit Fakultas Kedokteran Universitas Indonesia; 2009. hlm. 626-630.

2. World Health Organization. cancer. (diunduh 1 Mei 2018). Tersedia dari: URL: HYPERLINK http://www.who.int/en/newsroom/factsheets/detail $\angle$ cancer. 
3. Pemerintah Indonesia. Undang-Undang Republik Indonesia Nomor 13 tahun 1998. Jakarta: Sekretariat Negara; 1998.

4. Kemenkes RI. Infodatin situasi penyakit kanker. Jakarta: Pusat Data dan Informasi Kemenkes RI; 2015.

5. Halter JB, Ouslander JG, Tinetti ME, Studenski S, High KP, Asthana S. Hazzard's geriatric medicine and gerontology. New York: McGraw-Hill; 2009. hlm. 1123-35.

6. Kemenkes RI. Analisis lansia di Indonesia. Jakarta : Pusat Data dan Informasi Kemenkes RI; 2017.

7. Gillison TL, Chatta GS. Cancer chemotherapy in the elderly patient. J. Clin Oncol. 2010; 24(1): 76-85.

8. Sukardja I. Dasar kemoterapi kanker. Dalam: Sukardja I, editor (penyunting). Buku onkologii klinik. Surabaya: Airlangga University Press; 2000. hlm. 239.

9. Ikeda S, Yoshioka H, Ikeo S, Morita M, Sone N, Niwa T, et al. Serum albumin level as a potential marker for deciding chemotherapy or best supportive care in elderly, advanced non-small cell lung cancer patients with poor performance status. BMC cancer. 2017; 17: 797.

10. Ernita D. Gambaran respon kemoterapi pada pasien lansia dengan leukemia mieloblastik akut di RSUP Dr. M. Djamil Padang [Skripsi]. Fakultas Kedokteran: Universitas Andalas. Padang. 2018.

11. Alfiasari NR. Studi penggunaan obat kemoterapi pada pasien kanker paru [Skripsi]. Fakultas Farmasi: Universitas Airlangga. Surabaya. 2007.

12. Harahap WA, Arisanty D, Khambri D, Yanwirasti, Mubarikha S. At a glance epigenetic study in Padang, West Sumatera. J Breast. 2015; 24(3): 68.

13. Sulung N, Yananda R, Adriani. Determinan kejadian ca mammae di poli rawat jalan bedah RSUD Dr Achmad Moechtar. J Endurance. 2018; 3(3) :575-587.

14. National Cancer Institute. The Surveillance, Epidemiology, and End Results Cancer stat facts: laryngeal cancer. (diunduh 19 Februari 2019). Tersedia dari: URL: HYPERLINK https://seer.cancer.gov/ statfacts/html/laryn.html.

15. Cahyadi I, Permana AD, Afriani. Karakteristik penderita ca laring di departemen ilmu kesehatan telinga hidung tenggorok bedah kepala leher rumah sakit dr Hasan Sadikin Bandung periode januari 2013 - juli 2015. Tunas Medika: J. Kedokteran \& Kesehat(online). 2016; 3(1): 39-42.

16. Hurria A, Togawa K, Mohile SG. Predicting chemotherapy toxicity in older adults with cancer: a prospective multicenter study. J Clin Oncol. 2011; 29(25):3457-65.

17. Jerome K, Hurria A. Determining chemotherapy tolerance in older patients with cancer. J Natl Compr Canc Netw. 2013; 11(12): 1494-1502.

18. Ezeoke CC, Morley JE. Pathophysiology of anorexia in the cancer cachexia syndrome. J Cachexia Sarcopenia Muscle. 2015; 6(4): 287-302.

19. Owusu C, Cohen H, Feng T. Anemia and functional disability in older adults with cancer. J Natl Compr Canc Netw. 2015; 13(10): 1233-1239.

20. Mercadante S, Gebbia V, Marrazzo A. Anemia in cancer: pathophysiology and treatment. Cancer Treat Rev. 2000; 26(4): 303-11.

21. Macciò A, Madeddu C, Gramignano G. The role of inflammation, iron, and nutritional status in cancerrelated anemia: results of a large, prospective, observational study. Haematologica. 2015; 100(1): 124-132.
22. Connoly GC. Leukocytosis, thrombosis and early mortality in cancer patients initiating chemotherapy. Thromb Res. 2010; 126(2): 113-118.

23. Liebman HA. Thrombocytopenia in cancer patients. Thromb Res. 2014; 133(2): 63-9.

24. Shah AA, Patton M, Chishty WH. Analysis of elevated liver enzymes in an acute medical setting: jaundice may indicate increased survival in elderly patients with bacterial sepsis. Saudi J Gastroenterol. 2010; 16(4): 260-263.

25. Jorgensen T, Hallas J, Frilis F, Herstedt J. Comorbidity in elderly cancer patients in relation to overalland cancer-specific mortality. Br J Cancer. 2012; 106: $1353-60$

26. Shaiba R, McMillan DC, Angerson WJ, Leen E, Mcardle CS, Horgan P. The relationship between hypoalbuminemia, tumor volume and the systemic inflammatory response in patients with colorectal liver metastases. Br J Cancer. 2004; 91(2): 205-7.

27. Hwangbo Y, Lee EK. Acute hyperglycemia associated with anti-cancer medication. Endocrinol Metab. 2017; 32(1): 23-29.

28. Hurria A, Togawa K, Mohile SG, Owusu C, et al. Predicting Chemotherapy Toxicity in Older Adults With Cancer: A Prospective Multicenter Study. J Clin Oncol. 2011 Sep 1; 29(25): 3457-3465.

29. Weaver BA. How taxol/paclitaxel kills cancer cells. Mol Biol Cell. 2014 September; 25(18): 2677-81.

30. Dasari S, Tchounwou PB. Cisplatin in cancer therapy: molecular mechanisms of action. Eur J Pharmacol. 2014; 5: 364-78. 